\title{
SUOMEN TIETEELLISEN KIRJASTOSEURAN VUOSI 2018: VIESTINTÄÄ, VAIKUTTAMISTA JA VERKOSTOITUMISTA
}

\begin{abstract}
Miten seuramme vuosi meni? Istahdimme alas keskustelemaan puheenjohtaja Pälvi Kaiposen ja vuoden 2018 varapuheenjohtajan Irma Reijosen kanssa.
\end{abstract}

Uudistettiin viestintää ja viimeisteltiin historiikkia

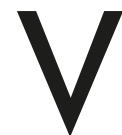

uoden 2018 tärkeimmäksi kehittämiskohteeksi valittiin viestintä. Seuran hallituksen ja monen puheenjohtajan pitkäaikainen haave, verkkosivujen uudistaminen, toteutui.

- Vaikka ensimmäisellä tapaamisellamme jäimmekin reiluksi vartiksi jumiin hissiin, yhteistyö visuaalisen ilmeen luoneen Mattsson \& Mattssonin kanssa sujui hyvin, kertoo Pälvi Kaiponen. - Verkkosivu-uudistusta oli valmisteltu pitkään ja sitä käsiteltiin kaikissa hallituksen kokouksissa viime vuonna. Toimihenkilöt tekivät suuren työn siirtäessään sisältöjä, kiitokset heille. Jonkin verran töitä on vielä jäljellä työryhmille ja toimihenkilöille sisältöjen siivoamisessa ja yhdenmukaistamisessa.

Uusilla sivuilla haetaan seuralle näkyvyyttä ja houkuttelevuutta. Yksi uusista ominaisuuksista on se, että seuran sosiaalisen median kanavien, Facebookin ja Twitterin, syötteet tulevat nyt verkkosivujen etusivulle.

- Sivusto on saanut hyvää palautetta. Koetaan, että sivut ovat nykyaikaiset ja raikkaammat.

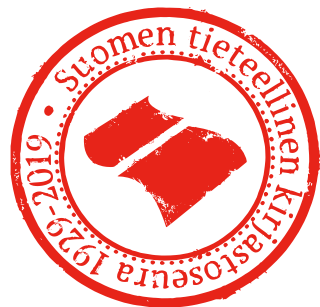

Toinen viestinnän vuoden painopistealueista oli Signum-lehden julkiasun kehittäminen.

- Tiedekustantajien liiton myöntämällä apurahalla pystyimme palkkaamaan graafisen suunnittelijan, kuvataiteilija Petri Fillsin, jonka tekemä visuaalisen ilmeen uudistus on kerännyt kehuja lukijoilta. Fills osoittautui niin hyväksi yhteistyökumppaniksi, että pyysimme häntä tekemään 
myös historiikkimme taiton.

Seuran historiikkia on valmisteltu useamman puheenjohtajan kaudella. Viime vuonna teosta viimeisteltiin, se taitettiin ja saatiin painokuntoon. Tuula Ruhasen ja Marja Sarvilinnan toimittama Muutoksen tekijät hyvässä seurassa. Suomen tieteellinen kirjastoseura 197020 I o julkaistiin alkuvuonna 2019. Sen tekemiseen on osallistunut suuri määrä seuran kokeneita konkareita.

\section{Otettiin kantaa}

Seura otti kantaa useisiin alan teemoihin viime vuonna. Tekijänoikeus ja tietosuoja olivat yksi ajankohtainen aihealue.

- Eurooppalaisen tutkimuskirjastojärjestön LIBERin pyynnöstä otimme yhteyttä suomalaisiin EU-parlamenttiedustajiin ja kerroimme heille järjestön tekijänoikeusdirektiiviä koskevasta vetoomuksesta. Seuran kirjastojuridiikkaryhmä seurasi Eu:n tietosuoja-asetuksen voimaantuloa tiiviisti, ja seura laati kannanoton oikeusministeriölle EU-asetusta täydentävästä kansallisesta tietosuojalaista. Seura teki myös oman tietosuojailmoituksensa, kertoo Pälvi Kaiponen.

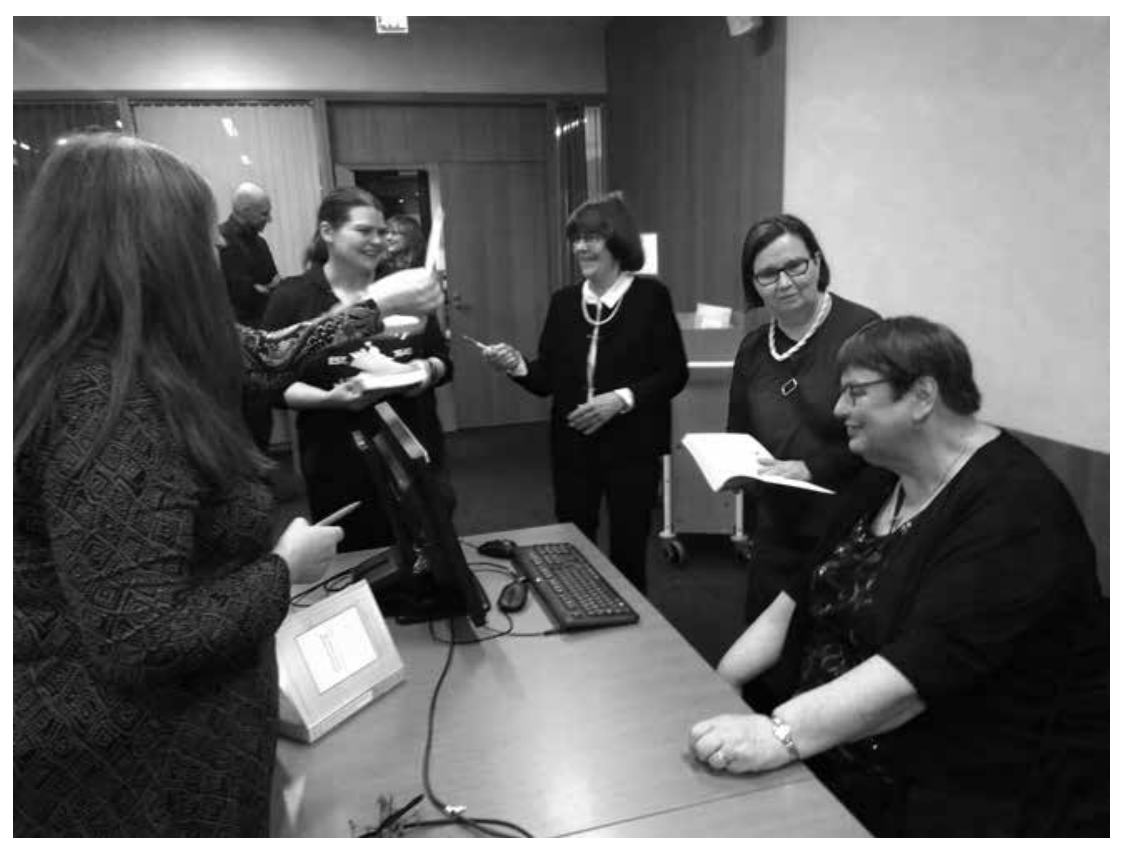

Helmikuussa 2019 seuran historiikin julkistamistilaisuudessa kävi kova vilske, kun kirjan toimittajat Tuula Ruhanen (oik.) ja Marja Sarvilinna (kolmas oik.) signeerasivat kirjoja. Nimikirjoitusten perässä olivat muun muassa Kaisa Sinikara (toinen oik.) ja Tuija Korhonen (neljäs oik.) Kirja Muutoksen tekijät hyvässä seurassa. Suomen tieteellinen kirjastoseura $1970-2010$ on tilattavissa BoD-kustantamolta (www.bod.fi) sekä painettuna että sähköisenä kirjana. 
- Seura asetti ehdokkaan оKM:n alaiseen tekijänoikeusneuvostoon. STKs:n juridiikkaryhmän Pekka Heikkisestä tuli neuvoston varajäsen.

Seura ja kirjastolaiset saavat aika ajoin oikoa väärinkäsityksiä rinnakkaistallennuksesta ja muusta avoimesta julkaisemisesta. FUN ja STKS kirjoittivat yhdessä mielipidekirjoituksen Acatiimi-lehteen, jossa käytiin keskustelua edellä mainituista aiheista.

Myös kirjastoalan koulutus on seuralle tärkeä puheenaihe. "Me olemme kirjastoalan tärkein täydennyskouluttaja”, toteaa Pälvi Kaiponen.

Koulutusleikkauksista huolestuneina Kaiponen ja Suomen kirjastoseuran Maria Bang kirjoittivat Helsingin sanomiin mielipidekirjoituksen Kirjastoalan koulutuksen tulevaisuus näyttää synkältä: Kirjastoalan korkeakoulutus on turvattava (HS I3.3.20I8).

\section{Kouluttauduttiin ja verkostoiduttiin}

Seuran työryhmät järjestivät kolme suosittua koulutustilaisuutta vuonna 2018.

Tietoaineistotyöryhmän seminaarissa Tietoaineistokallion loubintaa ja arviointia aiheina olivat aineistojen ja niiden hankinnan monet muodot ja mahdollisuudet.

Asiakaspalvelutyöryhmä järjesti $\mathrm{Pa}$ luu tulevaisunteen - asiakaspalveluympäristön undet kujeet ja vanhat metkut -seminaarin, jossa käsiteltiin robotteja, lukukoiria ja kirjastojen äänimaailmaa.

Informaatiolukutaito- ja tutkijapalvelutyöryhmän seminaarissa Koko kylä kasvattaa! pohdittiin avointa tiedettä, vastuullista metriikkaa ja dynaamista kumppanuutta tutkijoiden kanssa.

- Seuran jäsenet ovat toivoneet suosittujen koulutustemme lisäksi vapaamuotoisempaa toimintaa, kertoo Irma Reijonen. - Tämä toive täytettiin järjestämällä kierros Alvar Aallon suunnitteleman KELAn päärakennuksen kirjastossa, jonka jälkeen iltaa jatkettiin töölöläisessä Korjaamo-ravintolassa. Lisäksi Koko kylä kasvattaa! -seminaarin jälkeen pidettiin verkostoitumistapaaminen Otaniemen Fat Lizard -panimoravintolassa.

Tässä siis nostoja vuodesta, johon mahtui myös paljon muuta. Taas yksi innostunut ja työntäyteinen vuosi takana ja uusi täydessä vauhdissa. Seura täyttää 90 vuotta, mutta ikä ei paina eikä hidasta!

\section{Tietoa kirjoittajista:}

\author{
JoHANnA LAHIKAINEN \\ Signumin päätoimittaja \\ johanna.lahikainen@helsinki.fi
}

\author{
PÄlvi Kaiponen \\ STKS:n puheenjohtaja \\ palvi.kaiponen@helsinki.fi
}

\section{IRMA REIJONEN}

STKS:n varapuheenjohtaja vuonna 2018 irma.reijonen@helsinki.fi 